\title{
Students' difficulties in productive connective thinking to solve mathematical problems
}

\author{
Nurfaida Tasni $^{1}$, Andika Saputra ${ }^{1}$, Ovan Adohar $^{1}$
}

\begin{abstract}
Abstrak: Penelitian ini bertujuan mengidentifikasi kesulitan siswa membangun koneksi matematis dalam berpikir konektif produktif untuk memecahkan masalah matematika. Kesulitan siswa membangun koneksi matematis diidentifikasi dari tidak berkembangnya ide-ide koneksi setelah refleksi pada setiap tahapan kognitif Toshio (2000). Tehnik purposive sampling digunakan untuk memilih 2 dari 85 orang siswa kelas 11 yang telah mengikuti tes awal untuk mengukur kemampuan berpikir konektif. Lembar kerja, rekaman think aloud dan wawancara dari dua orang siswa dianalisis dengan pendekatan deskriptif kualitatif. Hasil analisis menunjukkan siswa mengalami berbagai kesulitan membangun koneksi. Pada tahap kognisi, siswa mengalami kesulitan membangun koneksi ide solusi karena siswa tidak mampu mengumpulkan data yang sesuai dan tidak melakukan verifikasi terhadap data awal yang dikumpulkan untuk memahami dan memikirkan arah penyelesaian masalah. Pada tahap inferensi, siswa mengalami kesulitan membangun koneksi prosedur karena siswa tidak menyusun rencana penyelesaian yang efektif. Pada tahap formulasi, siswa mengalami kesulitan membangun koneksi numerik karena siswa tidak melakukan proses verifikasi data dan tidak memiliki pemahaman konsep yang memadai untuk melakukan proses formulasi. Pada tahap rekonstruksi, siswa mengalami kesulitan membangun koneksi generalisasi karena siswa tidak memiliki motivasi untuk memecahkan masalah dan tidak melakukan proses generalisasi dan evaluasi secara menyeluruh terhadap proses pemecahan masalah.
\end{abstract}

\section{Kata kunci: Berpikir konektif, Koneksi matematis, Refleksi, Skema berpikir Toshio}

\begin{abstract}
The purpose of this study was to identify students' difficulties in establishing mathematical connections in productive connective thinking to solve mathematical problems. Students' difficulties were identified from which the students did not develop connection ideas after reflection at the stages of Toshio's (2000) cognition scheme. The purposive sampling was used to select 2 out of $8511^{\text {th }}$ grade students who had taken the initial test in order to measure their connective thinking. Students' works and the transcript of think-aloud and interviews with two students were analyzed using a qualitative descriptive approach. It reveals that students indicate various difficulties in developing connections. At the cognition stage, students had difficulty establishing a connection idea for solutions, since they were not able to collect appropriate data and did not verify the initial data to understand the direction of solving the problem. At the inference stage, students were difficult to establish a procedure connection because they could not plan an effective strategy of problemsolving. At the formulation stage, students had difficulty establishing numerical connections since they did not verify the data and did not have sufficient understanding of the concepts to formulate the problem. At the reconstruction stage, students found it difficult to establish generalization connections because of being not motivated to solve the problems and not doing a comprehensive generalization and evaluation towards the problem-solving.
\end{abstract}

Keywords: Connective thinking, Mathematical connections, Reflection, Toshio thinking scheme

\footnotetext{
${ }^{1}$ Department of Mathematics Education, STKIP YPUP Makassar, Jln Andi Tonro 17, Makassar, Indonesia, nurfaidatasniypupstkip@gmail.com
} 
Tasni, N., Saputra, A., \& Adohar, O.

\section{A. Introduction}

The connection is defined as a cognitive process in connecting or associating two or more ideas, concepts, definitions, theorems, procedures, and representations in both mathematics and other disciplines (García-García \& Dolores-Flores, 2018). Asik and Erktin (2019) explain that mathematical connection is needed in the problem-solving in an effort to find solutions based on the existing knowledge. It is also required to solve problems that require the relationship of mathematical concepts with other concepts in mathematics and other disciplines or in everyday life (Rohendi \& Dulpaja, 2013). This indicates that students' experience in solving problems is certainly not separated from the connection of mathematical ideas. In this case, Anthony and Walshaw (2009) argue that through the connection of mathematical ideas, the student can develop an understanding of the interrelated concepts or procedures to be used in solving problems. Furthermore, Eli et al. (2011) explain that when connections of mathematical ideas are used to solve mathematical problems and their applications in everyday life, students will become aware of the uses and benefits of mathematics. In conclusion, establishing the connections of mathematical ideas is absolutely required to solve mathematics problems successfully.

In solving mathematics problems, connecting mathematical ideas involves a thinking process called as connective thinking. Susanti (2015) defines connective thinking as a cognitive process to establish the connection of mathematical ideas which is categorized into three levels: simple, semi-productive, and productive connective. In simple connective thinking, mathematical ideas are only linked and cannot be used to construct new ideas needed in the problem-solving. Semi productive connective thinking is a level where mathematical ideas are linked and can only be interpreted as a simple problem-solving. In productive connective thinking, mathematical ideas that are linked can be used to construct new ideas to establish connected schemes in complex problem-solving. For example, a student is given a problem: Are $y_{1}-2 x+2=3$ and $y_{2}-2 x+4=2$ parallel? Student $\mathrm{A}$ is in simple connective thinking if he has ideas about two parallel lines and algebra operation, which lead him to just get $y_{1}=2 x-$ 1 and $y_{2}=2 x-2$ without further works, for example, determine the gradient. If student $\mathrm{B}$ proceed the prior student's work to connect $y_{1}$ and $y_{2}$ with the general form of line equation $y=m x+c$ which lead to the gradient of each line ( $m$, the coefficient of $x)$ and the conclusion that the two lines are parallel, then he reaches semi-productive thinking. Student $\mathrm{C}$ has productive connective thinking if he is not only able to identify the gradient as student B did but also come to $m_{1}=m_{2}=m$ then represent the lines in the Cartesian coordinate (graphical representation) to show the parallel of the two lines.

Constructivism emphasizes the process of constructing knowledge in a meaningful way which involves connecting ideas or prior knowledge to be a comprehensive one (Otting \& Zwaal, 2007). Thus, establishing the connections of mathematical ideas in problem-solving involves thinking to connect and organize relevant ideas. When students connect mathematical ideas, their understanding will last longer and witness mathematics as the whole one. Furthermore, constructivism sees mathematics connection as a bridge to link prior knowledge with new knowledge which strengthen the connection of ideas, concepts, procedures, or representations in the scheme (Hsu \& Silver, 2014). Singh et al. (2012) argue that if students can construct meaningful knowledge, connect related ideas, and connect ideas in the construction of knowledge comprehensively, then students will be able to construct comprehensive scheme independently. 
Every student has the potential to develop his/her thinking structures in connecting mathematical ideas in the problem-solving. Holyoak and Morisson (2012) explain that the connection of ideas could be developed through concrete experiences and the understanding of language, representation, and symbol of mathematics. In addition, Voorhees (2004) asserts that students who have incomplete thinking structures can be trained by establishing the pattern of systematic thinking. Despite the possibility to improve students' thinking, many students demonstrate an inability to connect mathematical ideas in a productive way (Tasni et al., 2017). In this case, it is essential to identify students' difficulties in connective thinking and the causes of difficulties so that we have insight on how to support students develop the productive level of connective thinking. Several researchers (e.g., Baki et al., 2009; Hendriana, Slamet, \& Sumarmo, 2014; Mhlolo, 2012; Stylianou, 2013; DeJarnette et al., 2016; Tasni \& Susanti, 2016; GarcíaGarcía \& Dolores-Flores, 2018) studied how students connect mathematical ideas in problemsolving. However, the studies have not focussed on the students' difficulties and its causes in establishing connections of mathematical ideas as the present study attempted to address. In identifying the cases, we used reflection practices (Reinholz, 2016) after and before students solve the given test and referred to Toshio's (2000) cognition scheme.

Students' reflection could be mean to improve their connective thinking. Leung and Kember (2003) explain that reflection involves careful consideration of each assumption or belief which base on someone's consciousness. Moreover, Pagano and Roselle (2009) elucidate that the first thing to be done in the reflection is to develop a cycle of knowledge by observing, re-organizing, and retaking the meaning based on the experiences to respond a problem. In specific, Reinholz (2016) argue that reflection can be utilized to develop mathematics ability, either in the micro or macro level. Reflection could occur with limited intervention from researchers. In this study, the students were given the first test (mathematics connection test) then a second related test was administered as a form of reflection. Additional information was added to the second test to stimulate students' connective thinking. Tasni et al., (2019) account two constructions to transform from simple to productive connective thinking in the reflection, namely correcting the connection errors established in the scheme of simple connective thinking and establishing an incomplete scheme of connections in the simple level.

Toshio (2000) proposes four stages of scheme development; cognition, inference, formulation, and reconstruction. In the first stage, students understand the problem and think of the direction of problem-solving. In the inference stage, students determine representative or appropriate logical information to plan a problem-solving. In the formulation stage, students verify the problem and decide to process and find a new knowledge through the mathematics scheme. In the last stage, students evaluate the preceding process, reconstruct all process of problem-solving, and generalize ideas to other domains. Toshio (2000) developed the stages to understand the formation of students' cognition scheme in geometry (Figure and space). It is utilized to examine the formation of mathematical connections. Thus, the stages are representative to be used in this study to identify students' difficulties in connecting mathematics ideas when working with geometrical problems such as origami ornament. The present study applied pre and post reflection in these stages.

The present study aimed to identify students' difficulties and its causes in establishing mathematical connections in productive connective thinking when solving mathematical problems. Theoretically, this study extends our knowledge to the question of why students fail to connect mathematical ideas in problem-solving. Empirically, we argue that by knowing the students' difficulties, mathematics educators can design a learning activity to address those 
difficulties and help students transform their connective thinking from simple to the productive level.

\section{B. Methods}

This study involved eighty-five $11^{\text {th }}$-grade students. The students were given a preliminary test that aims to categorize students' level of connective thinking- simple, semi-productive, and productive. The test comprises four problems about plane and number patterns. The test resulted in 59 students with simple connective thinking, 16 students with semi-productive thinking, and 7 students with productive thinking. The focus of the present study was to identify students' difficulties; thus, the subject selection was focused on groups of students who are unable to achieve the level of productive thinking or simple connective thinking and/or semi-productive connective thinking.

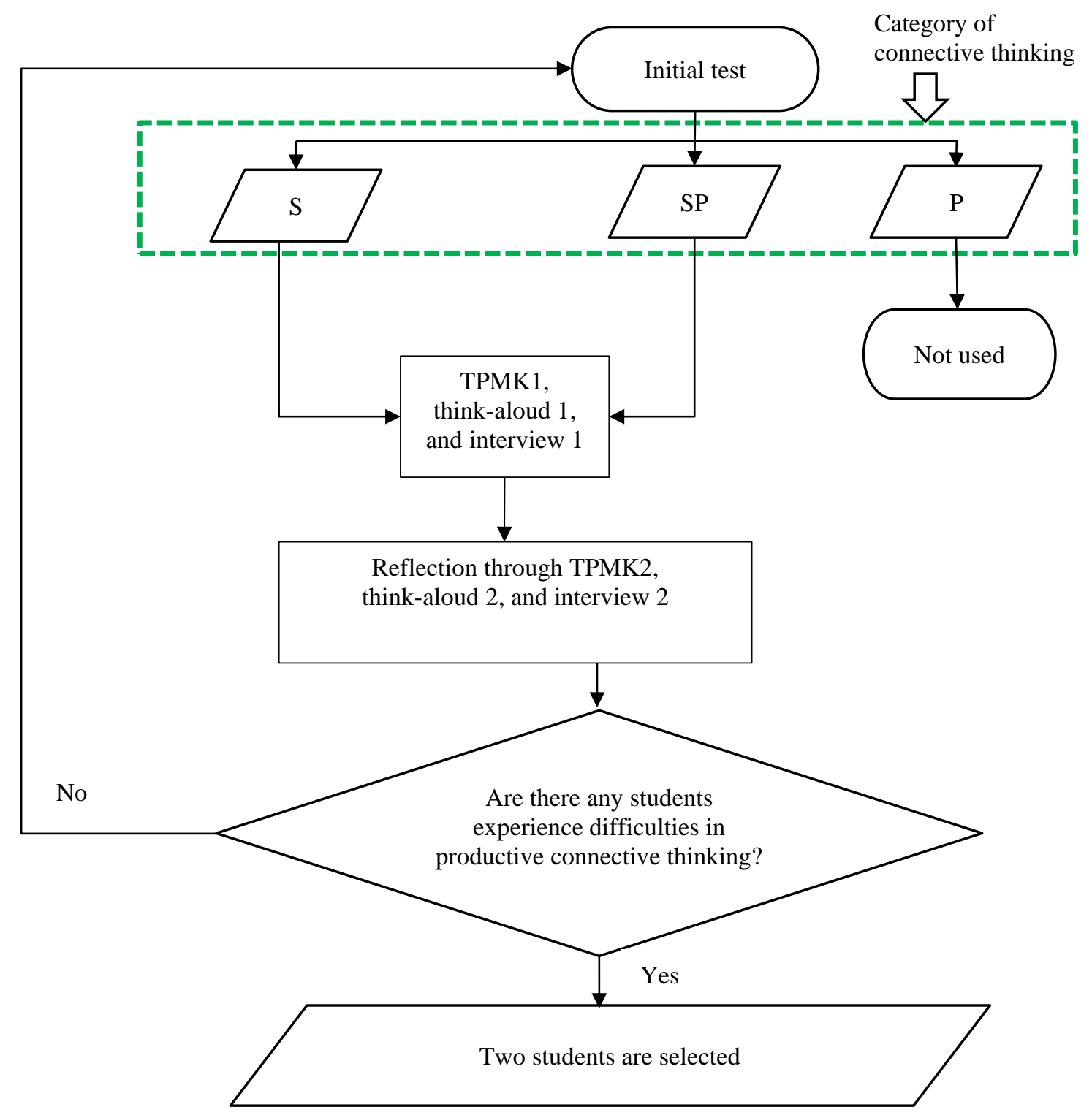

Notes: S (simple connective thinking), SP (semi-productive connective thinking), P (productive connective thinking)

Diagram 1. The selection of research subjects 
Afterwards, we administered second test (TPMK1 or mathematics connection test, See Appendix) with Think Aloud and interviews with 17 prospective subjects consisting of 14 students with simple connective thinking and 3 students with semi-productive thinking. The selection of 17 prospective subjects was on the basis of their willingness to participate in TPMK1, think aloud, and interview. Also, they were considered as having the ability to communicate both verbal and writing in order to obtain accurate data related to the focus of research. TPMK1 aimed to examine students' connective thinking before reflection. To identify students' difficulties in establishing mathematics connection at the productive level, the 17 students were provided with the chance to reflect: solve the third test (TPMK2) with Think aloud and interview. TPMK2 (See Appendix) is an extended problem of TPMK1 which can encourage students' thinking to establish new connection ideas to solve the third test. Thus, we argue that TPMK2 is a form of intervention and reflection, as well.

The results of two tests (TPMK1 before reflection, TPMK2 after reflection) along with Think aloud show that 15 students demonstrated the transformation of connective thinking to the higher level and two students remained in the simple level of connective thinking. Thus, the two students were selected as the subjects in this present study to identify their difficulties in connective thinking further using interview and existing think-aloud data and students' works. The causes of difficulties were identified by the existence of new connection ideas at each stage of Toshio's scheme development. Diagram 1 displays the procedures to select the subjects.

Data analysis followed these steps: (1) transcribe students' Think aloud when solving TPMK1 and TPMK2, (2) transcribe the results of the interview in which the interview validated students' works with Think aloud, (3) the transcripts of think-aloud and interview were categorized which refer to students' difficulties in establishing connections, (4) reduce unrelated data in the transcripts and students' works, (5) triangulate the reduced transcript of Think aloud, interview and students' works, (6) analyse the triangulated data by compiling students' structure of thinking in pre and post reflection which refer to four stages of scheme development (Toshio, 2000), and (7) students' difficulties and its causes were drawn based on students' thinking in pre and post reflection.

\section{Findings and Discussion}

This part presents students' structure of thinking at each stage of Toshio's (2000) cognition scheme before and after reflection drawn from students' works on TPMK, think aloud, and interview. Following this, we identify students' difficulties and their causes per stages. Then we discuss the findings. We coded the subjects as S1 and S2.

\section{Cognition stage}

At the stage of cognition before reflection, S1 just read the problem and could not develop understanding to solve it (Transcript 1, line 4). At the cognition stage after reflection, S1 completed TPMK II and provided an explanation of origami ornament, but she was not able to come up with new connections ideas that are adequate for designing problem-solving strategies (Transcript 2 line 4).

\section{Transcript 1}

$1 \quad P \quad: \quad$ What do you understand about origami ornament after reading the

2 S1 : The origami ornament is shaped like this picture... (The subject designates a level 1 and level 2 origami ornament) 
Tasni, N., Saputra, A., \& Adohar, O.

$3 \quad P \quad: \quad$ What can you explain from the picture?

4 S1 : Hmmm ... I'm still confused.

\section{Transcript 2}

$1 \quad P \quad: \quad$ After completing TPMK2, can you give an explanation about origami ornament?

2 S1 : The origami ornament was formed from the triangle arrangement

$3 \quad P \quad: \quad H o w$ can you find the pattern of triangular, rhombus, trapezium and polygon of the triangular arrangement?

4 S1 : Hmmm for the triangle pattern I can determine by counting one by one triangle, but the others seem difficult.

At the stage of cognition before reflection, S2 did not yet understand the problem (Transcript 3). At the cognition stage after reflection, S2 did not make any changes to her answers (Transcript 4).

\section{Transcript 3}

$1 \quad P \quad: \quad$ What do you understand about origami ornament in the problem?

2 S2 : Origami ornaments are formed from the arrangement of unit triangles arranged in a circle like a picture in the problem

$3 \quad P \quad: \quad H o w$ do you find the pattern of each plane to complete the table?

$4 \quad$ S2 : I can see the triangle pattern but to build the others, I have to first draw a level 3 origami ornament

\section{Transcript 4}

$1 \quad P \quad: \quad$ After drawing origami ornament, can you determine the amount of each level 3 planes?

$2 \quad$ S2 : Yes, here I have obtained the number of triangles with the side length of one unit is 9, two units are 3, for trapezium ... hmmm there are 9, rhombus 9 and polygon 2.

Transcript 1 and transcript 3 show that the students before reflection did not develop adequate connection ideas to collect appropriate data. After being given the opportunity to reflect, they had not been able to identify all the pattern of planes formed in the level 3 origami ornament. In this case, we identify the students have difficulty establishing solution idea connections. Collis, Watson, and Campbell (1993) explain that it is important to pay attention to the connection of ideas, concepts, and techniques to arrive at the right solution. The students experienced this difficulty due to incomplete connections about the patterns of each plane formed. Therefore, they were not able to collect appropriate data to design a problem-solving strategy in determining the number of planes at level 4 of origami ornament up to level 10. In this case, establishing connections between visualizations is important in the process of finding solutions to problems (El Mouhayar, \& Jurdak, 2013). Another possible factor that causes difficulties in connective thinking is that the students did not carry out the initial data verification, so they were unable to identify the error of the initial data collected which resulted in the students being unable to understand the problem situation and think about the direction of problem-solving. Papadopoulos and Dagdilelis (2008) explain that verification is an alternative form of calculation to check the correctness of the solution. In addition, Eizenberg and Zaslavsky (2004) assert that verification contributes to the successful resolution of problems. 


\section{Inference stage}

At the inference stage before reflection, S1 could only determine the triangle pattern with one-unit length in origami ornament. At the inference stage after reflection, S1 was able to identify the pattern of trapezium, rhombus, and polygon but she was not precise (Transcript 6)

Transcript 5

"... then to determine the number of planes in level 4 origami ornament I draw level 4 origami ornament like this again... then I count the number of triangles with one-unit length there are 16 pieces, triangles with two-unit lengths there are 16 pieces, for trapezium here it looks like there are 6 but is it really ... it looks like there are 7 ..."

\section{Transcript 6}

"... the number of triangles in level 4 origami ornament there are $1,2,3,4,5, \ldots 16$, there are 16 pieces, for triangles with two-unit length 1,2,3,4 ... 7 there are 7 pieces, for trapezium means the pattern is like this, $1,2,3,4$..... 20 there are 20 pieces ..."

At the inference stage before reflection, S2 was only able to find patterns for triangles with one-unit and two-unit length (Transcript 7). At the inference stage after reflection, S2 mistakenly determined the number of trapeziums in level 4 origami ornament (Transcript 8)

\section{Transcript 7}

"... Based on information about the origami ornament, it is composed of small triangles that are one unit in length, oohhh meaning that the number of triangles with the length of one unit in an origami ornament 1 level is 1 , for triangles with two-unit length ... Hmmm, it looks like it doesn't exist, for trapezium, it doesn't exist, for rhombus, it doesn't exist either ..."

\section{Transcript 8}

"... The number of triangles with one-unit length is $1,2,3, \ldots 16$, the triangle with two-unit length is $1,2, \ldots 7$, for trapezium $1,2,3,4 \ldots . .22, \ldots$ "

Transcript 5 to transcript 8 reveal that the students did not compile a proper strategy of solving the problem. They only used the drawing method as the only way to determine the number of each plane in origami ornament level 1 to level 4 and immediately determine the number of each plane in one drawing. Consequently, they were not focusing on identifying any plane patterns that should have been formed and the difficulty in determining the number of planes that could be formed at the next level of origami ornament. The students had difficulty in establishing connection procedures even though they had an initial understanding of each form of plane. Anthony (1996) explicates that when students have the strategic knowledge needed to solve existing problems but applying it in an ineffective way then they will have difficulty in establishing connection procedures. Furthermore, Suominen (2015) explains that the connection procedure occurs when one concept can be used to determine another concept.

The probable factors that cause the students' difficulties are not drawing up a decent plan to solve the problem since they did not focus on data collection and still used pictures as the only way to determine the number of planes formed. Schoenfeld (1992) explains that the lack of plan and review were significant factors contributing to the difficulty in solving problems. The students could have used other strategies such as number patterns and algebraic processes, although Wilkie (2016) explains a strong role of visualization in figural pattern tasks. However, because only using origami ornament pictures, the students were not able to construct the appropriate $\mathrm{U}^{\mathrm{n}}$ formula. Williams et al. (2011) argue that linking arithmetic and algebraic 
reasoning will give students access to understand problems and find solution pathways that lead to greater success in solving problems.

\section{Formulation stage}

At the formulation stage before reflection, S1 continued the calculation to determine the number of each plane that can be formed in origami ornament (Figure 1, the translation of table content could be seen in Appendix). At the formulation stage after reflection, S1 again tried completing the table but still filled the table with incorrect data because she was unable to identify any pattern of planes formed (Figure 2, the translation of table content could be seen in Appendix).

\begin{tabular}{|c|c|c|c|c|c|c|}
\hline \multicolumn{7}{|c|}{ Pertanyaan: } \\
\hline \multirow[t]{2}{*}{ No. } & \multirow[t]{2}{*}{$\begin{array}{c}\text { Tingkatan } \\
\text { Ormamen origami }\end{array}$} & \multicolumn{2}{|c|}{$\begin{array}{l}\text { Banyaknya } \\
\text { segitiga pada } \\
\text { ornamen } \\
\text { origami dengan } \\
\text { panjang sisi }\end{array}$} & \multirow{2}{*}{\begin{tabular}{|l} 
Banyaknya \\
belah \\
ketupat \\
yang \\
memuat \\
Dua \\
segitiga \\
satuan \\
\end{tabular}} & \multirow{2}{*}{$\begin{array}{l}\text { Banyaknya } \\
\text { trapesium } \\
\text { sama kaki } \\
\text { yang } \\
\text { memuat } \\
\text { Tiga } \\
\text { segitiga } \\
\text { satuan } \\
\end{array}$} & \multirow{2}{*}{\begin{tabular}{|l} 
Banyaknya \\
polygon \\
segi-enam \\
yang \\
memuat \\
Enam \\
Segitiga \\
satuan \\
\end{tabular}} \\
\hline & & $\begin{array}{l}\text { Satu } \\
\text { satuan }\end{array}$ & \begin{tabular}{|l|} 
Dua \\
satuan
\end{tabular} & & & \\
\hline 1. & Ornamen origami 1 Tingkat & 1 & 1 & 0 & 0 & 0 \\
\hline 2. & Ornamen origami 2 Tingkat & 4 & 4 & 3 & 3 & 0 \\
\hline 3. & Ornamen origami 3 Tingkat & 9 & 9 & 7 & 8 & 1 \\
\hline 4. & Ornamen origami 4 Tingkat & 16 & 16 & 12 & 1615 & 3 \\
\hline 5. & Ornamen origami 5 Tingkat & 25 & 25 & 18 & 24 & 6 \\
\hline 6. & Ornamen origami 6 Tingkat & 36 & 36 & 25 & 35 & 10 \\
\hline 7. & Ornamen origami 7 Tingkat & 49 & 49 & 33 & 48 & $15 \mathrm{~km}$ \\
\hline 8. & Ornamen origami 8 Tingkat & 64 & 64 & 42 & 63 & 212 \\
\hline 9. & Ornamen origami 9 Tingkat & 81 & 81 & 52 & 80 & 28 \\
\hline 10. & $\begin{array}{l}\text { Ornamen origami } 10 \\
\text { Tingkat }\end{array}$ & 100 & 100 & 63 & 99 & 36 \\
\hline \multicolumn{2}{|c|}{ Ornamen origami $\mathrm{n}$ tingkat } & $u_{n}=n^{2}$ & $u_{n}=n^{2}$ & & & \\
\hline
\end{tabular}

Figure 1. S1's work in the formulation stage before reflection

\begin{tabular}{|c|c|c|c|c|c|c|}
\hline \multicolumn{7}{|c|}{$\begin{array}{l}\text { Pertanyaan: } \\
\text { Berdasarkan informasi soal, lengkapilah tabel di bawah ini }\end{array}$} \\
\hline \multirow[t]{2}{*}{ No. } & \multirow[t]{2}{*}{$\begin{array}{c}\text { Tingkatan } \\
\text { Ornamen origami }\end{array}$} & \multicolumn{2}{|c|}{$\begin{array}{l}\text { Banyaknya segitiga } \\
\text { pada ornamen } \\
\text { origami dengan } \\
\text { panjang sisi }\end{array}$} & \multirow{2}{*}{\begin{tabular}{l|}
$\begin{array}{l}\text { Banyaknya } \\
\text { belah ketupat }\end{array}$ \\
$\begin{array}{l}\text { Dua } \\
\text { segitiga } \\
\text { satuan }\end{array}$ \\
\end{tabular}} & \multirow{2}{*}{\begin{tabular}{|l|}
$\begin{array}{l}\text { Banyaknya } \\
\text { trapesium } \\
\text { sama kaki } \\
\text { yang memuat }\end{array}$ \\
$\begin{array}{l}\text { Tiga } \\
\text { segitiga } \\
\text { satuan }\end{array}$ \\
\end{tabular}} & \multirow{2}{*}{\begin{tabular}{|l|} 
Banyaknya \\
polygon \\
segi-enam \\
yang \\
mermuat \\
Enam \\
Segitiga \\
satuan
\end{tabular}} \\
\hline & & $\begin{array}{l}\text { Satu } \\
\text { satuan }\end{array}$ & $\begin{array}{l}\text { Dua } \\
\text { satuan }\end{array}$ & & & \\
\hline 1. & Ornamen origami 1 tingkat & 1 & 0 & 0 & 0 & 0 \\
\hline 2. & Ornamen origami 2 tingkat & 4 & 1 & 3 & 3 & 0 \\
\hline 3. & Ornamen origami 3 tingkat & 9 & 3 & 9 & 10 & 1 \\
\hline 4. & Ornamen origami 4 tingkat & 16 & 7 & 18 & 21 & 3 \\
\hline 5. & Ornamen origami 5 tingkat & 25 & 17 & 30 & 36 & 6 \\
\hline 6. & Ornamen origami 6 tingkat & 36 & 21 & 45 & SI & 10 \\
\hline 7. & Ornamen origami 7 tingkat & 49 & 31 & 53 & 69 & 15 \\
\hline 8. & Ornamen origami 8 tingkat & 64 & 43 & 74 & 90 & 21 \\
\hline 9. & Ornamen origami 9 tingkat & 81 & 57 & 98 & 114 & $2 \theta$ \\
\hline 10. & Ornamen origami 10 tingkat & 100 & 73 & & & \\
\hline \multicolumn{2}{|c|}{ Ornamen origami n-tingkat } & $u_{n}=n^{2}$ & & $u_{n}=\left(n^{2}-2\right) \frac{1}{2}$ & $U_{n}=2 n^{2}-3 n+1$ & $y_{n}=3 n+2$ \\
\hline
\end{tabular}

Figure 2. S1's work in the formulation stage after reflection 
At the formulation stage before reflection, S2 had not made an appropriate formulation to determine the number of planes at each level of origami ornament (Figure 3). At the formulation stage after reflection, S2 again tried accomplishing the table but still could not identify any pattern of planes that are formed (Figure 4).

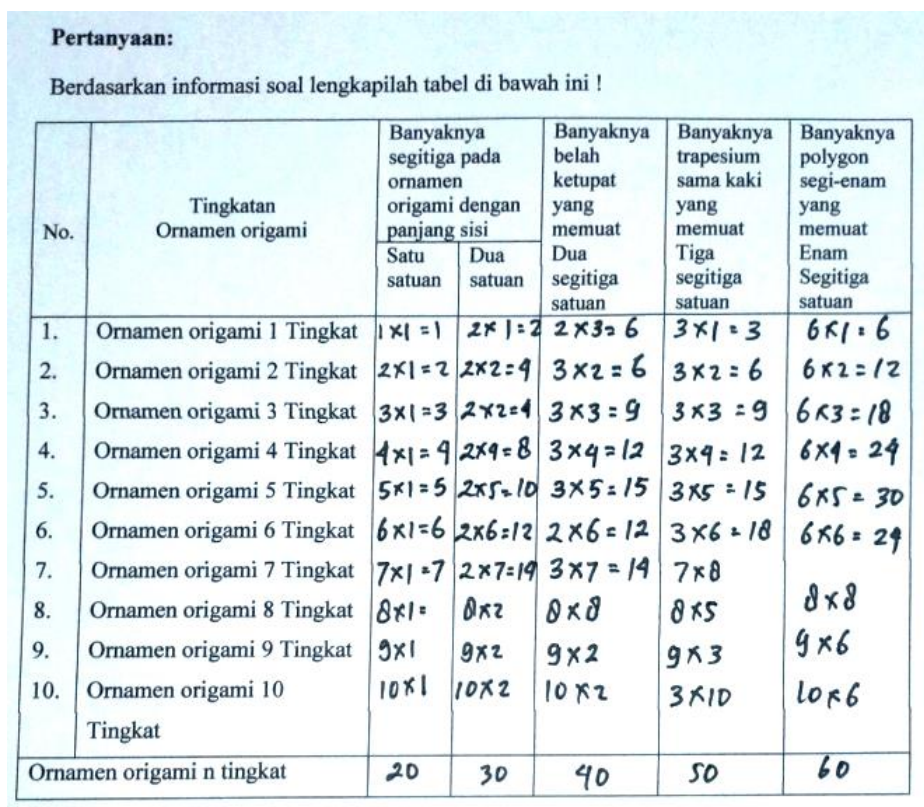

Figure 3. S2's work in the formulation stage before reflection

\begin{tabular}{|c|c|c|c|c|c|c|}
\hline \multicolumn{7}{|c|}{ Pertanyaan: } \\
\hline \multicolumn{7}{|c|}{ Berdasarkan informasi soal, lengkapilah tabel di bawah ini } \\
\hline \multirow[t]{2}{*}{ No. } & \multirow[t]{2}{*}{$\begin{array}{c}\text { Tingkatan } \\
\text { Ornamen origami }\end{array}$} & \multicolumn{2}{|c|}{$\begin{array}{l}\text { Banyaknya segitiga } \\
\text { pada ornamen } \\
\text { origami dengan } \\
\text { panjang sisi }\end{array}$} & \multirow{2}{*}{\begin{tabular}{|l|}
$\begin{array}{l}\text { Banyaknya } \\
\text { belah ketupat }\end{array}$ \\
$\begin{array}{l}\text { Dua } \\
\text { segitiga } \\
\text { satuan }\end{array}$ \\
\end{tabular}} & \multirow{2}{*}{\begin{tabular}{|l|}
$\begin{array}{l}\text { Banyaknya } \\
\text { trapesium } \\
\text { sama kaki } \\
\text { yang memuat }\end{array}$ \\
$\begin{array}{l}\text { Tiga } \\
\text { segitiga } \\
\text { satuan }\end{array}$ \\
\end{tabular}} & \multirow{2}{*}{\begin{tabular}{|l}
$\begin{array}{l}\text { Banyaknya } \\
\text { polygon } \\
\text { segi-enam } \\
\text { yang } \\
\text { memuat }\end{array}$ \\
$\begin{array}{l}\text { Enam } \\
\text { Segitiga } \\
\text { satuan }\end{array}$ \\
\end{tabular}} \\
\hline & & $\begin{array}{l}\text { Satu } \\
\text { satuan }\end{array}$ & $\begin{array}{l}\text { Dua } \\
\text { satuan }\end{array}$ & & & \\
\hline 1. & Ornamen origami 1 tingkat & 1 & 0 & 0 & 0 & 0 \\
\hline 2. & Ornamen origami 2 tingkat & 4 & 1 & 3 & 3 & 0 \\
\hline 3. & Ornamen origami 3 tingkat & 9 & 3 & 9 & 10 & 1 \\
\hline 4. & Ornamen origami 4 tingkat & 16 & 7 & 18 & 21 & 3 \\
\hline 5. & Ornamen origami 5 tingkat & 25 & 13 & 30 & 36 & 6 \\
\hline 6. & Ornamen origami 6 tingkat & 36 & 31 & 72 & 55 & 23 \\
\hline 7. & Ornamen origami 7 tingkat & 49 & 43 & 105 & 78 & 34 \\
\hline 8. & Ornamen origami 8 tingkat & 69 & 57 & 194 & 105 & 47 \\
\hline 9. & Ornamen origami 9 tingkat & 81 & 73 & 189 & 136 & 62 \\
\hline 10. & Ornamen origami 10 tingkat & 100 & 91 & 240 & 171 & 79 \\
\hline \multicolumn{2}{|c|}{ Ornamen origami n-tingkat } & $n^{2}$ & & $3 n^{2}-6 n$ & $2 n^{2}-3 n+1$ & $n^{2}-2 n-1$ \\
\hline
\end{tabular}

Figure 4. S2's work at the formulation stage after reflection

Students' works unravel that at the stage of formulation they were not able to accurately identify all the patterns of planes formed so that they obtained incorrect calculation at each level of origami ornament. This impacted on the inability of the students to identify formed number patterns. In this case, we identify that the students have difficulty establishing numerical connections. Siegler (2009) explains the connection between habits and accuracy of children 
with the development of numerical understanding. The factor that likely causes students' difficulties is that the students did not re-check when calculating the number of image patterns formed at each level of origami ornament. In this situation, the students did not verify the data. Papadopoulos and Dagdilelis (2008) argue that verification is an alternative calculation method to check the correctness of the solution or as a way for students to check the reasonableness of their choices. Montenegro et al. (2018) explain that errors are possible in the process of solving problems. Thus, verification is very necessary, especially if there are some quick and intuitive procedures as a way to test the suitability of the results or arguments obtained.

The students were able to complete the table for the number of triangles with the length of one unit because the drawing and number patterns are predictable. However, they could not determine triangles with two-unit length, rhombus, isosceles trapezium, and hexagon; the subject claimed not to be able to find the pattern of the numbers. The possible factor that causes the students' difficulty at this stage is the lack of understanding of the second-level arithmetic concept, so they are unable to present a different form of representation of the many plane patterns formed in origami ornament into the form of general rules through algebraic processes. Callejo and Zapatera (2014) explain the importance of students' knowledge of general rules in the process of finding solutions to problems through the algebra process. Altay, Akyüz, \& Erhan (2014) and El Mouhayar and Jurdak (2016) in their research on the ability of students to solve number patterns find the main problems faced by students, namely how to generalize patterns, strategies, and representations which they choose intending to find the relationship between the strategies adopted and the representations used.

\section{Reconstruction stage}

At the reconstruction stage before reflection, S1 was unable to reach this stage since she could not identify the formed pattern of numbers (Transcript 5). At the reconstruction stage after reflection, $\mathrm{S} 1$ attempted to find the $\mathrm{n}^{\text {th }}$ term formula for level $n$ origami ornament, as shown in Figure 5.

\section{Transcript 5}

$1 \quad P \quad: \quad$ After completing the table for the number of each plane formed in origami ornament level 1 up to level 10. How do you determine the general formula to determine the number of each plane in the origami ornament level $n$ ?

2 S1 : Hmmm ...... I'm confused. I can't see the corresponding number pattern of the sum of the triangular shapes with two-unit length, trapezium, rhombus and polygon .... hmmm maybe $n^{2}$... but it seems wrong.

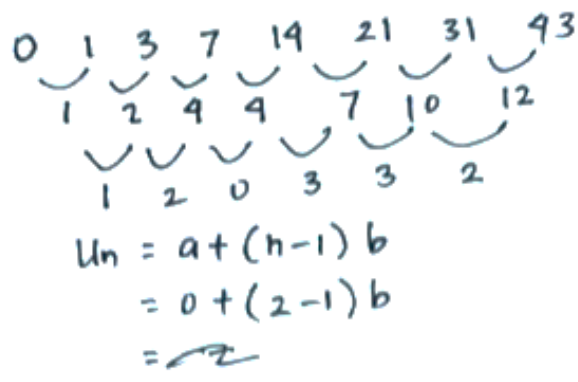

Figure 5. S1's work at the reconstruction stage after reflection 
In the reconstruction phase before reflection, $\mathrm{S} 2$ chose not to specify the $\mathrm{n}^{\text {th }}$ term formula for level $n$ origami ornament (Transcript 6). In the reconstruction phase after reflection, S2 had not shown the development of adequate connection ideas by not being able to find and construct a formula that is suitable for the number of hexagons in origami ornament (Figure 6).

\section{Transcript 6 \\ $1 \quad P \quad: \quad$ What do you do next to determine the $n^{\text {th }}$ term formula for level $n$ origami ornament? \\ $2 \quad$ S2 : Hmmm ....... I'm confused. I can't \\ $3 \quad P \quad: \quad$ Did you not try first? \\ $4 \quad S 2$ : $\quad H m m m$.... I can't yet. I can't see the relationship between a row of numbers there}

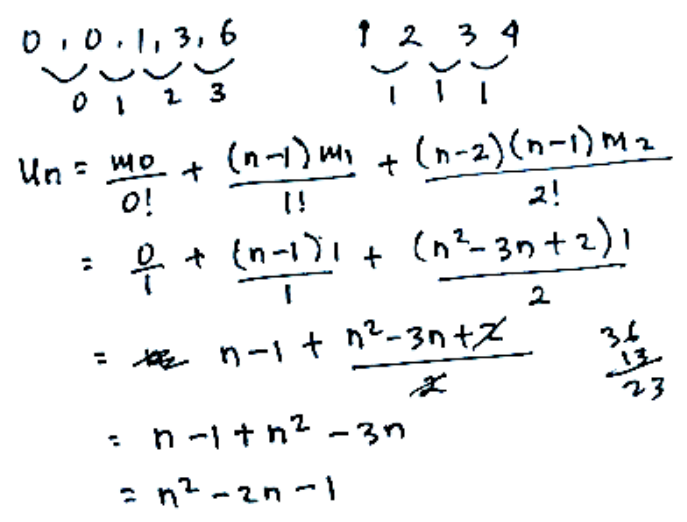

Figure 6. S2's work in the reconstruction stage after reflection

Transcript 5, transcript 6 , and students' works show that they were not able to establish connections to determine the $U n$ formula. In this case, the students have difficulty establishing generalization connections. Generalization can not be separated in the process of solving number pattern problems (Papadopoulos \& Iatridou, 2010). In Toshio's (2000) scheme, generalizations should occur at the reconstruction stage, but due to the error of generalization connection students have difficulty completing the reconstruction stage. Generalization is an important part of mathematics (the heart of mathematics), when students solve problems without using appropriate generalizations, solutions to problems will not be found (Mason, Stephens, \& Watson, 2009; Cooper \& Warren, 2008).

We observed that another possible factor that causes S1's difficulties in the stage of reconstruction is that she did not show a motivation to solve the problem. This is known from the absence of his efforts to improve the process of solving the problem. Francisco (2005) explicates that motivation is very important to possessed by students to develop ideas and mathematical reasoning based on reflections on their learning experiences (Francisco, 2005; Ozturk \& Guven, 2016).

Not verifying the data and evaluating problem-solving are the source of S2's difficulties. Although she generated a process of generalization by trying to find a general formula, the formula is incorrect. Montenegro et al., (2018) explain that errors are always possible in the process of solving problems, so verification is very necessary especially if there are some quick and intuitive procedures as a way to test the suitability of the results or arguments obtained. S2 did not realize his error in determining the $\mathrm{n}^{\text {th }}$ term formula since he did not carry out a thorough evaluation process. Papadopoulos and Dagdilelis (2008) have shown the importance of 
verification in problem-solving. They found that students did not verify systematic solutions to problems. Although the development of verification skills is very important to improve problemsolving abilities, students usually do not verify the accuracy of their final answers, and when they do so, it is often in the form of incomplete checks or just repetition of reassessments of what they have just completed (Schoenfeld, 1992; Pugalee, 2004).

\section{Conclusion}

This study found students' difficulties in the transformation of connective thinking from simple to productive level when solving mathematical problems at each stage of Toshio's (2000) cognition scheme development. The identified difficulties are establishing connection idea for solutions in the stage of cognition, making the procedures connection in the stage of inference, setting up numerical connections in the formulation stage, and producing generalization connection in the reconstruction stage. The difficulties in connective thinking occur since the students do not develop connection ideas after reflection. The students' structure of thinking is relatively the same: It does not tend to change towards a more productive direction after reflection. The possible sources of those difficulties relate to students' inability to: collect representative data dan verify initial data to understand the direction of problem-solving, plan an effective strategy to solve the problem, understand the mathematics concepts, evaluate the process of solving the problem, and even motivation to solve the problem. We believe that these findings provide valuable insight and entry point to design a learning activity which facilitates students' difficulties in connective thinking

\section{Acknowledgment}

The authors would like to thank SMA Negeri 9 Bulukumba, South Sulawesi Indonesia, that permit the study to be carried out in the school and provide valuable assistance. The errors or inconsistencies found in this article remain our own.

\section{References}

Altay, M. K., Akyüz, E. Ö., \& Erhan, G. K. (2014). A Study of middle grade students' performances in mathematical pattern tasks according to their grade level and pattern presentation context. Procedia Social and Behavioral Sciences, 116, 4542-4546. Doi: 10.1016/j.sbspro.2014.01.982

Anthony, G. (1996). When mathematics students fail to use appropriate learning strategies. Mathematics Education Research Journal, 8(1), 23-37. Doi:10.1007/BF03217287

Anthony, G., \& Walshaw, M. (2009). Characteristics of effective teaching of mathematics. Journal of Mathematics Education, 2(2), 147-164.

Asik, G., \& Erktin, E. (2019). Metacognitive experiences: Mediating the relationship between metacognitive knowledge and problem solving. Education and Science, 44(197), 85-103. Doi: 10.15390/EB.2019.7199

Baki, A., Çatlioğlu, H., Coştu, S., \& Birgin, O. (2009). Conceptions of high school students about mathematical connections to the real-life. Procedia - Social and Behavioral Sciences, 1(1), 14021407. Doi: 10.1016/j.sbspro.2009.01.247

Callejo, M. L., \& Zapatera, A. (2014). Flexibilidad en la resolución de problemas de identificación de patrones lineales en estudiantes de educación secundaria [Secondary school students' flexibility when solving problems of recognition of lineal patterns]. Bolema, 28(48), 64-88. Doi: 10.1590/1980$4415 \mathrm{v} 28 \mathrm{n} 48 \mathrm{a} 04$ 
Collis, K. F., Watson, J. M., \& Campbell, K. J. (1993). Cognitive functioning in mathematical problem solving during early adolescence. Mathematics Education Research Journal, 5(2), 107-123. Doi: 10.1007/BF03217190

Cooper, T. J., \& Warren, E. (2008). The effect of different representations on year 3 to 5 students' ability to generalise. ZDM - International Journal on Mathematics Education, 40(1), 23-37. Doi: 10.1007/s11858-007-0066-8

DeJarnette, A. F., González, G., Deal, J. T., \& Rosado Lausell, S. L. (2016). Students' conceptions of reflection: Opportunities for making connections with perpendicular bisector. Journal of Mathematical Behavior, 43, 35-52. Doi: 10.1016/j.jmathb.2016.05.001

Eizenberg, M. M., \& Zaslavsky, O. (2004). Students’ verification strategies for combinatorial problems. Mathematical Thinking and Learning, 6(1), 15-36. Doi: 10.1207/s15327833mt10601_2

Eli, J. A., Mohr-Schroeder, M. J., \& Lee, C. W. (2011). Exploring mathematical connections of prospective middle-grades teachers through card-sorting tasks. Mathematics Education Research Journal, 23(3), 297-319. Doi: 10.1007/s13394-011-0017-0

El Mouhayar, R., \& Jurdak, M. (2013). Teachers' ability to identify and explain students' actions in near and far figural pattern generalization tasks. Educational Studies and Mathematics, 82(3), 379-396. Doi: 10.1007/s10649-012-9434-6

El Mouhayar, R., \& Jurdak, M. (2016). Variation of student numerical and figural reasoning approaches by pattern generalization type, strategy use, and grade level. International Journal of Mathematical Education in Science and Technology, 47(2), 197-215. Doi: 10.1080/0020739X.2015.1068391

Francisco, J. M. (2005). Students' reflections on their learning experiences: Lessons from a longitudinal study on the development of mathematical ideas and reasoning. The Journal of Mathematical Behavior, 24(1), 51-71. Doi: 10.1016/j.jmathb.2004.12.005

García-García, J., \& Dolores-Flores, C. (2018). Intra-mathematical connections made by high school students in performing calculus tasks. International Journal of Mathematical Education in Science and Technology, 49(2), 227-252. Doi: 10.1080/0020739X.2017.1355994

Hendriana, H., Slamet, U. R., \& Sumarmo, U. (2014). Mathematical connection ability and selfconfidence (An experiment on junior high school students through contextual teaching and learning with mathematical manipulative). International Journal of Education, 8(1), 1-11.

Holyoak, K. J., \& Morisson, R. G. (2012). Thinking and reasoning: A reader's guide. New York: Oxford University Press. Doi: 10.1093/oxfordhb/9780199734689.001.0001

Hsu, H.-Y., \& Silver, E. A. (2014). Cognitive complexity of mathematics instructional tasks in a Taiwanese classroom: An examination of task sources. Journal for Research in Mathematics Education, 45(4), 460-496. Doi: 10.5951/jresematheduc.45.4.0460

Leung, D. Y. P., \& Kember, D. (2003). The relationship between approaches to learning and reflection upon practice. Educational Psychology: An International Journal of Experimental Educational Psychology, 23(1), 61-71. Doi: 10.1080/01443410303221

Mason, J., Stephens, M., \& Watson, A. (2009). Appreciating mathematical structure for all. Mathematics Education Research Journal, 21(2), 10-32. Doi: 10.1007/BF03217543

Mhlolo, M. K. (2012). Mathematical connections of a higher cognitive level: a tool we may use to identify these in practice. African Journal of Research in Mathematics, Science and Technology Education, 16(2), 176-191. Doi: 10.1080/10288457.2012.10740738

Montenegro, P., Costa, C., \& Lopes, B. (2018). Transformations in the visual representation of a figural pattern transformations in the visual representation of a figural pattern. Mathematical Thinking and Learning, 20(2), 91-107. Doi: 10.1080/10986065.2018.1441599

Otting H., \& Zwaal, W. (2007). The identification of constructivist pedagogy in different learning environments. In M.K. McCuddy., H. van den Bosch, W.B. Martz, A.V. Matveev, \& K.O. Morse. (Eds). The challenges of educating people to lead in a challenging world. Educational innovation in economics and business (pp.171-196). Springer, Dordrecht. Doi: 10.1007/978-1-4020-5612-3_9

Ozturk, T., \& Guven, B. (2016). Evaluating students' beliefs in problem solving process: A case study. Eurasia Journal of Mathematics, Science and Technology Education, 12(3), 411-429. Doi: 10.12973/eurasia.2016.1208a

Pagano, M., \& Roselle, L. (2009). Beyond reflection through an academic lens: refraction and international experiential education. Frontiers: The Interdisciplinary Journal of Study Abroad, 18(1), 217-229. Doi: 10.36366/frontiers.v18i1.263 
Tasni, N., Saputra, A., \& Adohar, O.

Papadopoulos, I., \& Dagdilelis, V. (2008). Students' use of technological tools for verification purposes in geometry problem solving. The Journal of Mathematical Behavior, 27(4), 311-325. Doi: 10.1016/j.jmathb.2008.11.001

Papadopoulos, I., \& Iatridou, M. (2010). Modelling problem-solving situations into number theory tasks: the route towards generalisation. Mathematics Education Research Journal, 22(3), 85-110. Doi: 10.1007/BF03219779

Pugalee, D. K. (2004). A comparison of verbal and written descriptions of students' problem solving processes. Educational Studies in Mathematics, 55(1/3), 27-47. Doi: 1023/B:EDUC.0000017666.11367.c7

Reinholz, D. L. (2016). Developing mathematical practices through reflection cycles. Mathematics Education Research Journal, 28(3), 441-455. Doi: 10.1007/s13394-016-0175-1

Rohendi, D., \& Dulpaja, J. (2013). Connected Mathematics Project (CMP) model based on presentation media to the mathematical connection ability of junior high school student. Journal of Education and Practice, 4(4), 17-22.

Schoenfeld, A. H. (1992). Learning to think mathematically: Problem solving, metacognition, and sensemaking in mathematics. In D. Grouws (Ed.), Handbook for research on mathematics teaching and learning (pp. 334-370). New York: MacMillan

Siegler, R. S. (2009). Improving the numerical understanding of children from low-income families. Child Development Perspectives, 3(2), 118-124. Doi: 10.1111/j.1750-8606.2009.00090.x

Singh, A., Yager, S. O., Yutakom, N., Yager, R. E., \& Ali, M. M. (2012). Constructivist teaching practices used by five teacher leaders for the Iowa chautauqua professional development program. International Journal of Environmental and Science Education, 7(2), 197-216.

Stylianou, D. A. (2013). An examination of connections in mathematical processes in students' problem solving: Connections between representing and justifying. Journal of Education and Learning, 2(2), 23-35. Doi: 10.5539/jel.v2n2p23

Suominen. (2015). Abstract algebra and secondary school mathematics: Identifying and classifying mathematical connections (Doctoral Dissertation). Athens, Georgia: The University of Georgia. Retrieved from https://getd.libs.uga.edu/pdfs/suominen_ashley_1_201505_phd.pdf

Susanti, E. (2015). Proses berpikir siswa dalam membangun koneksi ide-ide matematis pada pemecahan masalah matematika [Students' thinking to connect mathematics ideas in problem solving] (Unpublished dissertation). Malang: Universitas Negeri Malang.

Tasni, N., Nusantara, T., Hidayanto, E., Sisworo, S., \& Susanti, E. (2017). Obstacles to students' productive connective thinking in solving mathematical problems. Jurnal Pengajaran MIPA, 22(2), 46-55.

Tasni, N., Nusantara, T., Hidayanto, E., Sisworo, S., \& Susanti, E. (2019). The construction of student's thinking transformation: From simple connective to productive. Journal of Physics: Conference Series, 1157(3), 1-6. Doi: 10.1088/1742-6596/1157/3/032094

Tasni, N., \& Susanti, E. (2016). Membangun koneksi matematis siswa dalam pemecahan masalah verbal [Developing students' mathematical connections in solving verbal problems]. Beta: Jurnal Tadris Matematika, 10(1), 103-116. Doi: 10.20414/betajtm.v10i1.108

Toshio, O. (Ed). (2000). A curriculum improvement of "figure \& space". Tokyo: Toyokan Publishing Co, Ltd.

Voorhees, B. (2004). Embodied mathematics. Journal of Consciousness Studies, 11(9), 83-89.

Williams, C., Akinsiku, O., Walkington, C., Cooper, J. L., Ellis, A., Kalish, C., \& Knuth, E. (2011). Understanding students' similarity and typicality judgments in and out of mathematics. In L. R. Wiest \& T. Lamberg (Eds.), Proceedings of the 32nd annual meeting of the North American Chapter of the International Group for the Psychology of Mathematics Education (pp. 1180-1189). Reno, NV, USA: University of Nevada, Reno.

Wilkie, K. J. (2016). Learning to teach upper primary school algebra: Changes to teachers' mathematical knowledge for teaching functional thinking. Mathematics Education Research Journal, 28(2), 245275. Doi: 10.1007/s13394-015-0151-1 


\section{Appendix}

\section{TPMK1}

The wall decoration is made from origami (called origami ornament) made of unit triangles. The origami ornament is attached to the wall as follows.

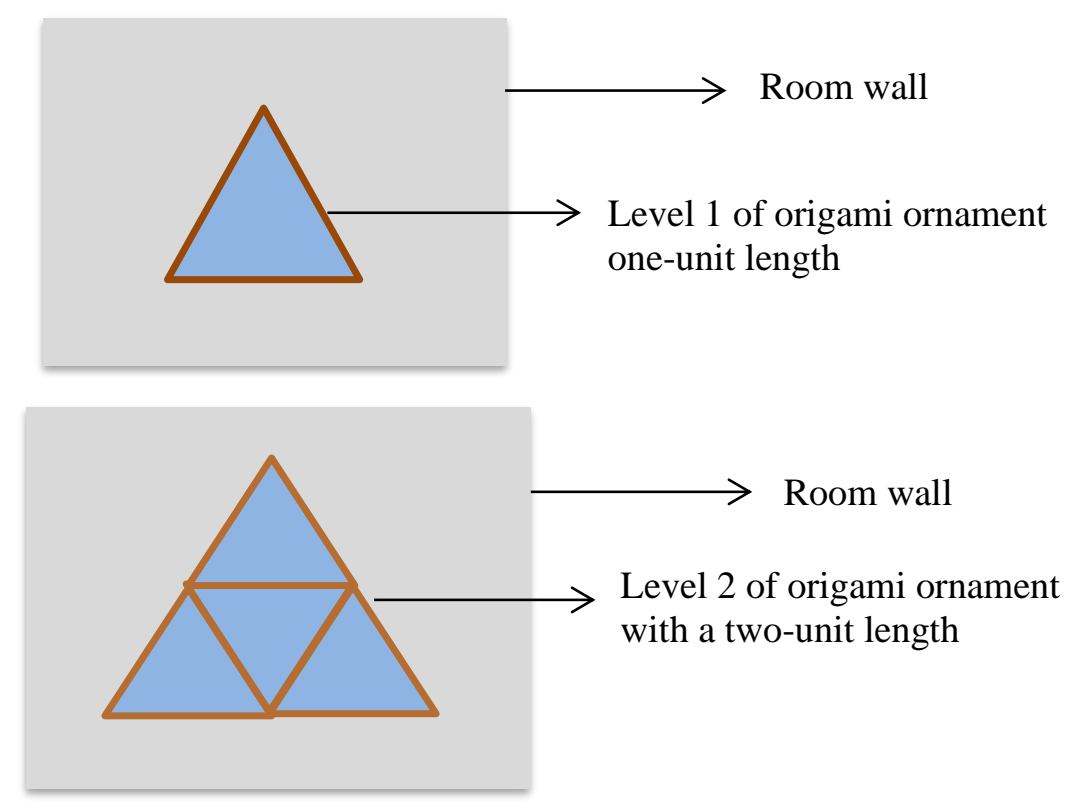

With the given information of wall decoration, fill the table below!

\begin{tabular}{|c|c|c|c|c|c|c|}
\hline \multirow[t]{2}{*}{ No. } & \multirow[t]{2}{*}{$\begin{array}{l}\text { The level } \\
\text { of origami } \\
\text { ornament }\end{array}$} & \multicolumn{2}{|c|}{$\begin{array}{c}\text { The number of triangles } \\
\text { in the origami ornament } \\
\text { with .. }\end{array}$} & \multirow{2}{*}{$\begin{array}{l}\text { The number of } \\
\text { rhombi } \\
\text { comprising } \\
\text { two unit- } \\
\text { triangles }\end{array}$} & \multirow{2}{*}{$\begin{array}{l}\text { The number } \\
\text { of isosceles } \\
\text { trapezoids } \\
\text { comprising } \\
\text { three unit- } \\
\text { triangles }\end{array}$} & \multirow{2}{*}{$\begin{array}{l}\text { The number of } \\
\text { six-sided } \\
\text { polygons } \\
\text { comprising six } \\
\text { unit-triangles }\end{array}$} \\
\hline & & One-unit & Two-unit & & & \\
\hline 1 & Level 1 & $\ldots$ & $\ldots$ & $\ldots$ & $\ldots$ & $\ldots$ \\
\hline 2 & Level 2 & $\ldots$ & $\ldots$ & $\ldots$ & $\ldots$ & $\ldots$ \\
\hline 3 & Level 3 & $\ldots$ & $\ldots$ & $\ldots$ & $\ldots$ & $\ldots$ \\
\hline 4 & Level 4 & $\ldots$ & $\ldots$ & $\ldots$ & $\ldots$ & $\ldots$ \\
\hline 5 & Level 5 & $\ldots$ & $\ldots$ & $\ldots$ & $\ldots$ & $\ldots$ \\
\hline 6 & Level 6 & $\ldots$ & $\ldots$ & $\ldots$ & $\ldots$ & $\ldots$ \\
\hline 7 & Level 7 & $\ldots$ & $\ldots$ & $\ldots$ & $\ldots$ & $\ldots$ \\
\hline 8 & Level 8 & $\ldots$ & $\ldots$ & $\ldots$ & $\ldots$ & $\ldots$ \\
\hline 9 & Level 9 & $\ldots$ & $\ldots$ & $\ldots$ & $\ldots$ & $\ldots$ \\
\hline 10 & Level 10 & $\ldots$ & $\ldots$ & $\ldots$ & $\ldots$ & $\ldots$ \\
\hline & Level $n^{\text {th }}$ & $\ldots$ & $\ldots$ & $\ldots$ & $\ldots$ & $\ldots$ \\
\hline
\end{tabular}




\section{TPMK2}

The wall decoration is made from origami (called origami ornament) made of unit triangles. The origami ornament is attached to the wall as follows.

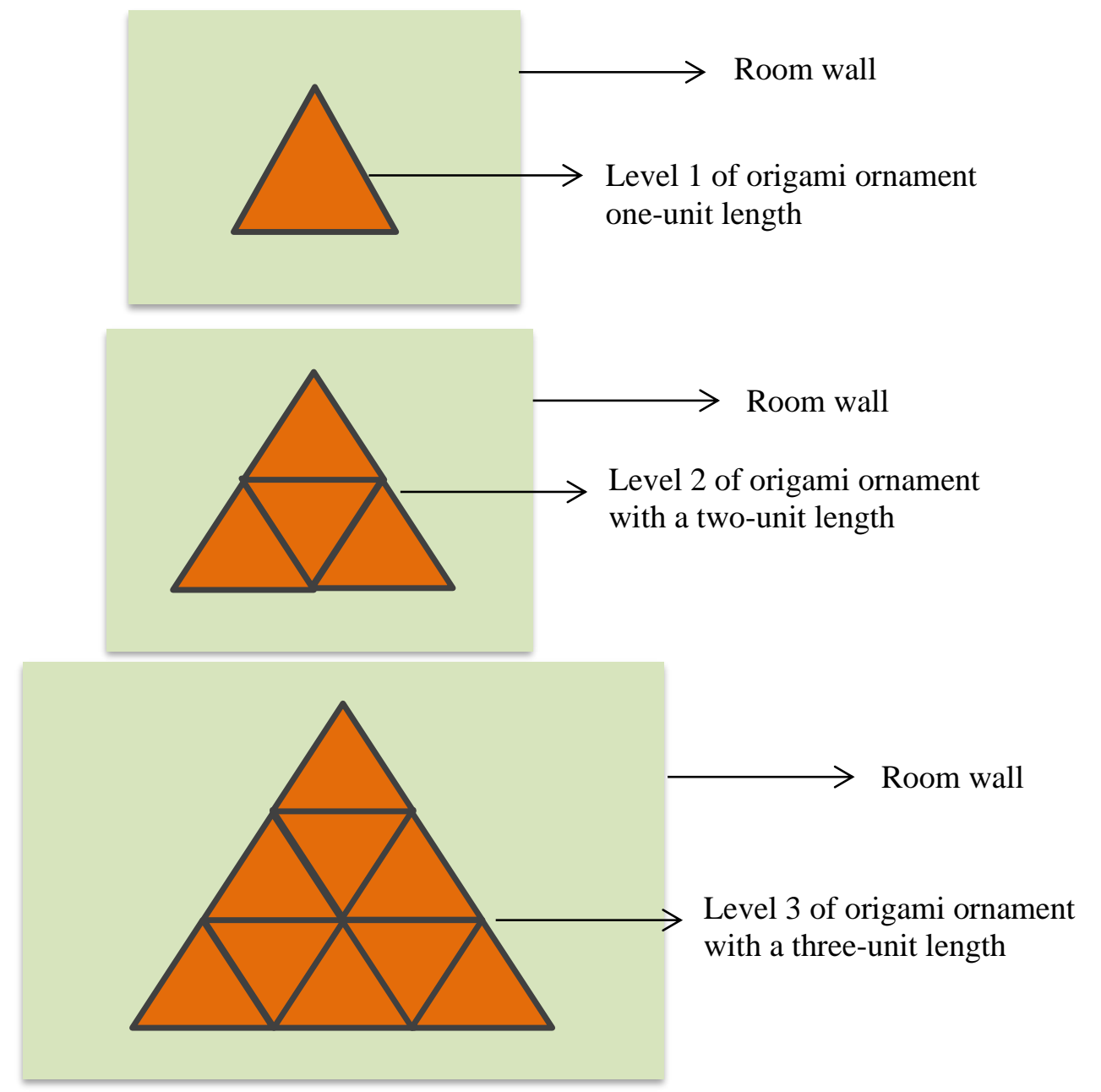

With the given information of wall decoration, fill the table below!

\begin{tabular}{|c|c|c|c|c|c|c|}
\hline \multirow[t]{2}{*}{ No. } & \multirow[t]{2}{*}{$\begin{array}{l}\text { The level } \\
\text { of origami } \\
\text { ornament }\end{array}$} & \multicolumn{2}{|c|}{$\begin{array}{l}\text { The number of triangles } \\
\text { in the origami ornament } \\
\text { with .. }\end{array}$} & \multirow{2}{*}{$\begin{array}{l}\text { The number of } \\
\text { rhombi } \\
\text { comprising } \\
\text { two unit- } \\
\text { triangles }\end{array}$} & \multirow{2}{*}{$\begin{array}{l}\text { The number } \\
\text { of isosceles } \\
\text { trapezoids } \\
\text { comprising } \\
\text { three unit- } \\
\text { triangles }\end{array}$} & \multirow{2}{*}{$\begin{array}{l}\text { The number of } \\
\text { six-sided } \\
\text { polygons } \\
\text { comprising six } \\
\text { unit-triangles }\end{array}$} \\
\hline & & One-unit & Two-unit & & & \\
\hline 1 & Level 1 & $\ldots$ & $\ldots$ & $\ldots$ & $\ldots$ & $\ldots$ \\
\hline 2 & Level 2 & $\ldots$ & $\ldots$ & $\ldots$ & $\ldots$ & $\ldots$ \\
\hline 3 & Level 3 & $\ldots$ & $\ldots$ & $\ldots$ & $\ldots$ & $\ldots$ \\
\hline 4 & Level 4 & $\ldots$ & $\ldots$ & $\ldots$ & $\ldots$ & $\ldots$ \\
\hline 5 & Level 5 & $\ldots$ & $\ldots$ & $\ldots$ & $\ldots$ & $\ldots$ \\
\hline 6 & Level 6 & $\ldots$ & $\ldots$ & $\ldots$ & $\ldots$ & $\ldots$ \\
\hline 7 & Level 7 & $\ldots$ & $\ldots$ & $\ldots$ & $\ldots$ & $\ldots$ \\
\hline 8 & Level 8 & $\ldots$ & $\ldots$ & $\ldots$ & $\ldots$ & $\ldots$ \\
\hline 9 & Level 9 & $\ldots$ & $\ldots$ & $\ldots$ & $\ldots$ & $\ldots$ \\
\hline 10 & Level 10 & $\ldots$ & $\ldots$ & $\ldots$ & $\ldots$ & $\ldots$ \\
\hline & Level $n^{\text {th }}$ & $\ldots$ & $\ldots$ & $\ldots$ & $\ldots$ & $\ldots$ \\
\hline
\end{tabular}

